\section{Interdisciplinary progress in approaches to address social-ecological and ecocultural systems}

\author{
JULES PRETTY* \\ Interdisciplinary Centre for Environment and Society and Department of Biological Sciences, University of Essex, \\ Wivenhoe Park, Colchester C04 3SQ, UK
}

Date submitted: 4 May 2010; Date accepted: 10 November 2010;

First published online: 10 February 2011
THEMATIC SECTION

Interdisciplinary Progress

in Environmental

Science \& Management

\section{SUMMARY}

The emergent human cultures have shaped, and in turn been shaped by, local ecosystems. Yet humanity's intense modification of the environment has resulted in dramatic worldwide declines in natural and cultural capital. Social-ecological systems are becoming more vulnerable through the disruption of livelihoods, governance, institutions, resources and cultural traditions. This paper reviews the environmental sub-disciplines that have emerged to seek solutions for conservation and maintenance of the resilience of social-ecological systems. It shows that a central component is engagement with the knowledges of people within their contexts. Local knowledges of nature (traditional, indigenous, local ecological knowledge and ecoliteracy) are used by place-based cultures to guide actions towards nature. The importance of new engagements between different knowledges is now becoming more widely recognized by scientific institutions. Yet there still exist many false dualisms (for example local knowledge versus science) which tend to emphasize a superiority of one over the other. Ecocultures retain or strive to regain their connections with the environment, and thus improve their own resilience. Revitalization projects offer ways to connect knowledge with action to produce optimal outcomes for both nature and culture, suggesting that systems can be redesigned by emphasis on incorporation of local and traditional knowledge systems.

Keymords: ecocultures, interdisciplinarity, local knowledge, resilience, revitalization, social-ecological systems

\section{THE SCALE OF THE CHALLENGE}

An unprecedented combination of pressures is emerging to threaten the health of social and ecological systems across the world. Continued population growth, rapidly changing consumption patterns and the signals of climate change are driving limited resources of food, energy, water and materials towards and beyond critical thresholds (Royal Society 2009; Godfray et al. 2010; Zalasiewicz et al. 2010). Modernity has

\footnotetext{
*Correspondence: Jules Pretty e-mail: jpretty@essex.ac.uk
}

brought astonishing technological advances, but it is also a story of natural and cultural capital eroding beneath swift currents of change. It is now evident that human-environment systems are intimately linked in ways that are only just beginning to be appreciated (Pretty et al. 2007, 2010; Escobar 2008). In some circumstances a society or culture can be resilient to perturbations (shocks and stresses), but in others it may become too vulnerable to be able to sustain itself. Resilience refers to the capacity of a system to absorb or even benefit from changes to the system, and so persist without a qualitative change in structure (Holling 1973; Adger et al. 2005; Walker et al. 2006; Costanza et al. 2007; Darnhofer et al. 2010). Vulnerability generally refers to instances when systems lack resilience and robustness, so being driven to rapid change, chaos or collapse (Berkes et al. 2005; Diamond 2005; Costanza et al. 2007; Pretty 2007), and is thus a reflection of both the state of systems and their absence of capacity to adapt (Berkes et al. 2003; Adger 2005).

Certain combinations of cultural and ecological components build system resilience: natural capital that delivers a flow of ecosystem goods and services; social capital in the form of relations of trust, norms, obligations and institutions fundamental for collective action; human capital in the form of knowledge, skills and capabilities to produce the technologies for well-being; and physical and financial capital that provide infrastructure and financial resources (Posey 1999; Pretty 2003). This current period of human history, termed the anthropocene for humanity's intense modification of the environment, has resulted in dramatic worldwide declines in renewable capital assets (MA [Millennium Ecosystem Assessment] 2005; Pilgrim et al. 2008; Zalasiewicz et al. 2010). These concerns are not entirely new, and have been foreshadowed by the concerns of the Club of Rome in the 1970s, the more measured tones of the Brundtland Commission in the late 1980s, the growing evidence base of the International Panel on Climate Change and Millennium Ecosystem Assessment in the 1990s and 2000s, and the as yet unmet aspirations of the Millennium Development Goals of the 2000s.

What is new, though, is the growing recognition that as social-ecological systems are more vulnerable than formerly predicted, so there need to be new approaches to address both problems and potential solutions (Adger 2005). A socialecological system is a system of people and nature with some kind of clear set of boundaries and where neither is seen as pre-eminent (Folke et al. 2007). A key concern is whether 
human institutions will act quickly enough to avoid severe non-linearities, or whether they will simply be in responsive mode (MA 2005; Folke et al. 2007; Brown 2008; Jackson 2009). Globalization seems to have acted in two ways: more intense and pervasive disturbance (increased spatial scales and altered temporal impacts), while at the same time undermining the local resilience of systems to cope. The immense challenge suggests it will take a combination of natural and social science disciplines combined with economic, social, political, legal and management expertise to analyse and develop solutions to address these challenges (Pretty et al. 2010).

The objectives of this review are to (1) assess the state of the problem of disconnection; (2) analyse the emergence of new sub-disciplines and knowledge links; (3) show with examples how socio-cultural institutions shape landscapes; (4) propose how ecocultures as an overarching term helps in the understanding of resilience and context for action; (5) show how cross-cultural research can be effective in revealing new insights to land management and agriculture; and (6) illustrate how revitalization projects are providing the context for renewal and establishment of new ways of living with the potential for positive ecological and cultural outcomes. In these ways systems can be redesigned (therefore requiring transformation) by discovery of and emphasis on local and traditional knowledge systems.

\section{THE CRISIS OF DISCONNECTION}

Humans have evolved in natural environments over several million years. Their emergent cultures have shaped, and in turn been shaped by, local ecosystems and their constituent parts (Balée 1994; Norgaard 1994; Denevan 2001; Maffi 2001; Toledo 2001; Gunderson \& Holling 2002; Harmon 2002; Sutherland 2003; Pretty 2007; Pilgrim \& Pretty 2010). A healthy system is able to maintain functionality in times of stress, i.e. it is resilient to incremental changes and perturbations. The diversity of a system (both components and functions) is frequently used as a proxy for health, since a diverse system generally has more adaptive capacity and is therefore more likely to cope with change. However there have been unparalleled losses in biological and cultural diversity in recent decades. As a consequence, both human and ecological systems are becoming disrupted in terms of livelihoods, governance, institutions, resource pools and cultural traditions (Ostrom 1990; Abel et al. 2006; Folke et al. 2007).

Many causes of biodiversity loss are also responsible for the loss of cultural diversity. Despite this, the loss of biodiversity is still considered as a separate policy issue to that of cultural diversity. Yet both have undergone an unprecedented rate of decline in recent decades, shifting towards monocultures of the land, people and mind. Common drivers of such erosion include shifts in consumption patterns (Pretty 2007), the globalization of food systems (Berkes 2001), and the commodification of natural resources. These drivers are reinforced by pressures of assimilation (integration of minority or different cultures into dominant society) and urbanization, and are at their most damaging when they lead to rapid and unanticipated periods of socioeconomic change, jeopardizing institutions and norms that may have been able to maintain system resilience.

Extreme natural events comprise one of the most rapid drivers of change, particularly when coupled with anthropogenic stressors (Rapport \& Whitford 1999; MA 2005). Tools commonly used in externally-imposed resource management also create common drivers and threats, such as exclusion policies (for example some nature-reserves or state-imposed management systems). A lack of transboundary cooperation and geopolitical instability threaten global diversity, as do weak institutions and a lack of resources which both affect the capacity for people from different disciplines or contexts from finding common solutions. Amplifying this is the widespread harm to natural capital for rapid economic returns.

Disconnection from the land (in the form of non-regular contact) has the capacity to damage and even destroy cultures that have been closely tied to their environments. The effects of dispossession often create political and social discord, leading to psychological, physical and financial dependency on the state (Cernea 1997; Alfred 2009). This, in turn, can lead to mental and psychological ills (Albrecht 2010) which often also manifest as physical ailments and social pathologies, particularly if disconnection is rapid. Ills include increasing prevalence of conditions such as obesity, type II diabetes, hypertension and coronary heart disease, as physical activity decreases and diets shift from traditional (often wild) to bought foods. Mental ill-health is also associated with reduced time in the natural environment (Basso 1996; Samson 2003; Samson \& Pretty 2006; Johnston et al. 2007; Pretty 2007; Alfred 2009; Barton \& Pretty 2010). Thus an unprecedented combination of pressures is emerging to threaten the health of human and ecological systems, by forcing communities towards or over critical thresholds, leading to vulnerability and decline. These threats are paving the way to the homogenization of cultures and landscapes (Maffi 2001; MA 2005; Rapport 2006; Pretty et al. 2007; Albrecht 2010).

\section{THE EMERGENCE OF NEW SUB-DISCIPLINES AND KNOWLEDGE LINKS}

A wide variety of novel environmental sub-disciplines have emerged to address the intersections of social, cultural and ecological systems (Table 1). Core social science disciplines have developed terms to describe different subfields of environmental conservation, such as environmental or ecological anthropology, environmental politics, ecological economics and environmental history (Kates et al. 2001; Clark \& Dickson 2003; Rapport 2006; Dove \& Carpenter 2008). Others help to explore bridges between different disciplines, particularly between the natural and social sciences, and so give rise to many combinations of theories, assumptions, methods and applications (Mascia et al. 2003; Berkes 2004; Mascia 2006). 
Table 1 Selection of sub-disciplinary fields concerned with intersection of social, cultural and ecological systems (see Pretty et al. 2010)

\begin{tabular}{ll}
\hline \hline Agricultural sustainability & Environmental sociology \\
Anthropology of nature & Ethnobiology \\
Biocultural diversity & Ethnobotany \\
Cognitive anthropology & Enthnoecology \\
Commons studies & Ethnolinguistics \\
Cultural anthropology & Ethnoscience \\
Cultural geography & Historical ecology \\
Cultural (landscape) ecology & Human ecology \\
Deep ecology & Human geography \\
Descriptive historical & Indigenous knowledge \\
$\quad$ particularism & Intercultural education \\
Development studies & Landscape ecology \\
Ecofeminism & Nature society theory \\
Ecological anthropology & Political ecology \\
Ecological design & Resilience sciences (ecological \\
Ecological economics & and cultural) \\
Ecosystem health & Science and technology \\
Environmental anthropology & studies \\
Environmental education & Social-ecological systems \\
Environmental ethics & Sustainability science \\
Environmental history & Symbolic ecology \\
Environmental law & Systems ecology \\
\hline \hline
\end{tabular}

Most of these sub-disciplines appear to be working towards similar ends, yet at times can remain non-integrative and autonomous (such as conservation science that does not consider local people), leading to a lack of coordination between the advancement of scientific knowledge and the development of national and international policies drawn up to protect cultural and biological capital and socialecological systems. What is required is better integration to produce clearer ideas on the relationships between biological and cultural systems in the hope of achieving a sustainable future where both ecological and social systems are resilient to external pressures through the maintenance of diversity (Rapport 2006). Research and development policies and practice need combined approaches that centre on conservation of diversity both in socialecological systems (Kates et al. 2001; Clark \& Dickson 2003), and in knowledges of different groups of people within their contexts (Gadgil et al. 2000; Williams 2009). Such integration to produce interdisciplinary or transdisciplinary research requires attention to (1) choice of appropriate disciplines, (2) a process by which they work together, (3) an agreement that disagreements will not result in individuals withdrawing, and finally (4) care that not every discipline should be involved at any one time (focused bilateral arrangements are more likely to work than efforts to bring every possible discipline together unless trust is very high) (Pretty et al. 2007).

Berkes (2001) indicated that the interactions between knowledge-belief-practice are key to understanding the locational subtleties of nature and culture. Local knowledge of nature (termed variously traditional knowledge, indigenous knowledge, local ecological knowledge and ecoliteracy) is accumulated within a society and transferred through varying modes of transmission, such as stories and narratives (Pilgrim et al. 2007, 2008). It comprises a compilation of observations and understandings contained within social memory that try to make sense of the way the world behaves. Cultures then use this collective knowledge to guide their actions towards the natural world (Berkes 2001; Turner \& Berkes 2006).

One reason for natural scientists' tendency to overlook, or even dismiss, local knowledge is that it is rarely generalizable (Jacobson \& Stephens 2009; Williams 2009). It tends to be locally-distinct, place-based and set within a local cultural context. Yet the importance of this knowledge is becoming more widely recognized by scientists and scientific institutions around the world. Stephenson and Moller (2009), in discussing the interrelations between local knowledge and modern science, emphasized the value and need to integrate both forms of knowledge capital, providing that both are taken within their respective cultural, spiritual and social contexts. They argued that scientists need to go beyond the false dualism (local knowledge versus science) which emphasizes a superiority of one form and inferiority of the other, and towards an understanding of the role that different knowledge bases can play in the future of conservation and environmental management.

Jacobson and Stephens (2009) similarly stated that any unchallenged dichotomy, such as that placed on local knowledge and science or between one strand of science and another, results in sub-optimal outcomes. However, they also warned of the risks associated with 'value-free' science, and suggested that it is important to understand the continuities and values of both sides of any dichotomy, without compromising the distinctiveness or integrity of either. Different types of knowledge, for instance, are embedded within their respective belief systems, and employ different modes of enquiry as a result. By opening up to the multiple legitimate voices that exist, conservation research will become more integrative, working both with and for local indigenous and marginal groups, in order to begin to understand the complex human-ecological interactions that exist. Such partnerships are critical if these systems are to be better understood. Thus there is a need in future conservation research for both modern science, which emphasizes knowledge seeking, and local knowledge, which emphasizes knowledge holding (Stephenson \& Moller 2009).

Berkes (2009) also considered the relationship between modern science and traditional knowledge for the future of conservation. A key difference between both forms of knowledge is that the latter tends to focus on process (how things are done or come to be known) rather than content (the information within the knowledge). Evidence for this and the up-to-date nature of local knowledge is explicit when considering indigenous peoples' understandings of current climate change. Elders are unable to transmit knowledge on the impacts of climate change, as most are relatively recent; they 
can however teach processes of knowledge acquisition and development. This is leading to a better understanding of local ecosystem dynamics relating to global climate change within traditional resource-dependent societies. Furthermore, local knowledge recognizes and appreciates the multiple levels of interconnections that exist between nature and culture, which modern day science is striving so hard to come to terms with.

On this basis, there is a need to integrate the sciences and local knowledge; these two frameworks no longer need to exist in opposition. Perhaps the most significant aspect of local knowledge is that it derives from frequent interactions with the land, which would be impossible if communities were disconnected (either physically or psychologically) from their own lands. Local knowledge is based on being able to read the signs and signals of the land, and then make sense of these observations. These cultural understandings of the environment not only can give rise to sustainable management practices, but also to knowledge of species requirements, ecosystem dynamics, sustainable harvesting levels and ecological interactions (Pilgrim et al. 2007, 2008). If sustained through stories, ceremonies and regular discourse, this culturally-ingrained knowledge can enable its holders to live within the constraints of the local environment, without the need for catastrophic learning in the event of major resource depletion (Turner \& Berkes 2006). Thus, it can be perceived as a form of cultural insurance for the future, providing a source of creativity and innovation, as well as a range of solutions for coping with future challenges. In this way, languages can be described as a resource for nature; a growing body of literature now exists on the multiple interconnections between linguistic, cultural and biological diversity (Maffi 1998, 2001).

But one challenge in integrating local knowledge with modern science is persuading researchers and scientists to accept that there are different ways of knowing, based on culture, semiotics and values, and all have an integrity and distinctiveness that makes them valuable to the future of conservation (Berkes 2009). Instead of trying to blend these different knowledge bases, it should be possible to appreciate and respect their different epistemologies and cultural contexts, in order to form cross-cultural partnerships for the benefit of human and ecological systems as a whole. Thus the challenge is to move beyond researching local knowledge and to start integrating such local knowledge into research.

\section{SOCIOCULTURAL INSTITUTIONS AND THEIR ROLE IN SHAPING LANDSCAPES}

There is growing acknowledgement that culturally-created landscapes are worthy of identification and protection. Conservation, though, does not only derive from an intention to conserve. It can arise from belief systems that comprise human religions and are embodied in a diversity of social institutions. The great majority of non-industrial societies that have succeeded in protecting the productivity of their ecosystems have done so primarily through the use of local cultural institutions (Costanza et al. 2007). One of the keys to their success is the manifestation of nature as spiritual, culturally-powerful symbols that command a sense of respect, and are, in some cases, revered by society (such as the dreamings by Aboriginal peoples in Australia). Many cultures have independently evolved informal regulations, norms and social taboos that govern the respectful treatment of nature, and which have evolved into forms of environmental ethics (such as in the protection of sacred groves).

Cultural (non-market based) institutions co-evolve with specific ecosystems over time and act to define locallyacceptable practices and behaviours, and in some cases, have a greater influence than external market signals. Thus when considering 'agri-cultural' systems (Pretty 2002), it is important to understand the interactions between culture and agro-biodiversity in terms of identity, cosmology and religion, ecological knowledge, language and aesthetics, social position and status, and common property rights and regimes.

Humans have a long history of developing regimes and rules to protect and preserve natural places in a steady state. These diverse and location-specific rule systems form informal institutional frameworks within communities, legitimated by shared values. Often termed tenure systems, these frameworks have regulated the use of private and common property throughout history, for instance by defining access rights and appropriate behaviours (Ostrom 1990; Turner \& Berkes 2006). Where these systems are robust, they can maintain the productivity and diversity of the natural environment without the need for formal legal enforcement sanctions. Compliance derives from shared values and informal internally-derived community sanctions, such as moral influence from elders. In some places, formalized payment mechanisms have been put in place to reinforce these norms and reward societies for the environmental services their ways of life maintain.

Socially-embedded norms and institutions therefore arise from a combination of local knowledge bases, cultural belief systems and distinct worldviews. These contextual systems of collective action are intimately linked to the land upon which they are based and, subsequently, are enormously diverse. They govern the use of resources across a wide range of contexts, from forests to fisheries, demonstrating remarkable diversity and flexibility. How humans know the world, therefore, governs behaviour and practices that in turn shape landscapes, which form a cultural archive of human endeavours (Adams 1996). Amidst a diversity of cultures comes a diversity of meanings, leading to a diversity of actions, and providing an array of biodiversity outcomes. This natureculture continuum or interconnection has existed through the past and into the present, and is therefore likely to be sustained in the future.

\section{ECOCULTURES AS A CONTEXT FOR RESILIENCE}

It is evident that human and environment systems are intimately linked in ways that are only just being appreciated 
(Pretty et al. 2007), and certain cultural and ecological components are necessary to ensure system resilience without losing critical functioning (Holling 1973; Costanza et al. 2007). However, due to recent and intense periods of diversity loss (both biological and cultural), there is now a growing recognition that human and ecological systems are more vulnerable than formerly predicted. Ideas around what can be called 'ecocultures' may provide guidance in creating novel, diverse and sustainable paths into the future (Westley et al. 2002; Berkes et al. 2003; Pilgrim \& Pretty 2010).

I suggest there are a limited number of common cultural dimensions which define and shape human interactions and relationships with the natural environment. The following five factors seem to be present where there is high resilience in ecocultures, irrespective of local ecological, social or political circumstances (Walker et al. 2006; Folke et al. 2007; Costanza et al. 2007; Stephenson \& Moller 2009; Albrecht 2010; Darnhofer et al. 2010; Pilgrim \& Pretty 2010):

(1) The intersection of technologies and knowledge results in 'internalizing technologies' that build natural capital and produce and use high ecological literacy.

(2) The social structure and relations are typified by high social capital (bonding, bridging and linking), meshworks and latticeworks of relations, heterarchies rather than hierarchies and regular intergenerational contact.

(3) Personal behaviours and choices are characterized by mixed diets and adequate calories, physically activity levels that maintain health, and regular access to and use of land/nature.

(4) The presence of internal beliefs, where strong cultural, spiritual or religious norms and beliefs differentiate one culture from another.

(5) The presence of adaptive policies and management, where policies and practices can adapt to conditions and thus tend to be emergent.

The levels of resilience in communities thus centres on the intersection between technology (how to transform capital assets) and social capital (the arrangements of trust that build collective actions). There are four sectors of natural capital (environmental) space (Fig. 1), according to whether technologies are internalizing (build natural capital) or externalizing (harm natural capital), and whether social capital is high or low. The arrows show potential pathways of development. Modernist development tends to move into space defined by externalizing technologies (that lose costs by transferring them to other systems) and lowering social capital. Beyond critical thresholds, it is theorized that this territory is characterized by risk spirals, where conditions become very much worse. Building resilience will be achieved by transitions to inbound pathways, in which social capital and its institutions results in outcomes that conserve natural capital.

Ecocultures comprise human cultures that have retained, or strive to regain, their connection with the local environment,

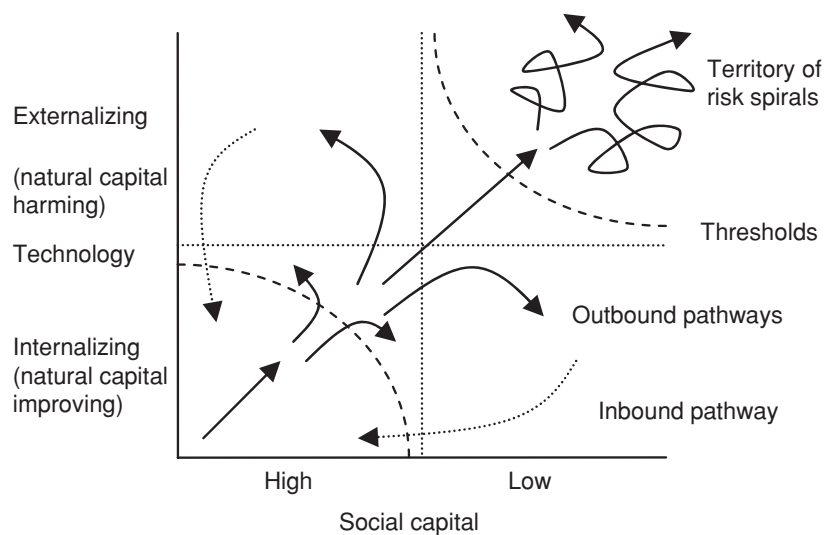

Figure 1 Pathways in intersection of technology and social capital in natural capital space. This shows that high social capital is associated with technologies that improve natural capital, but technologies that externalize costs are associated with low social capital. Development pathways have tended to take cultures and societies towards and across thresholds where both natural and social capital diminish rapidly. A challenge for the future is to find inbound pathways where technologies and practices are embedded with and contribute to high natural and social capital.

and in doing so, could be improving their own resilience in light of the many pressures they face, including global climate change. The term ecoculture represents the inextricable links and interplay that can be observed between ecological and cultural systems (Stephenson 2007; Rotarangi \& Russell 2009; Pilgrim \& Pretty 2010). This term is not being used as a replacement to the widely accepted socioecological system concept, but more an advancement of this notion, where ecocultural systems not only comprise the social institutions and distinct frameworks of a community, but also the worldviews, identity, values, distinct cultural practices and behaviours that make a community or group culturally distinct. Thus the phrase 'ecocultural resilience' can be used to emphasize the need to adopt an holistic approach to resilience-building as a consequence of the interconnected complexity of human and ecological systems. Rotarangi and Russell (2009) argued that 'social-ecological resilience has so far mostly been discussed in the absence of critical cultural dimensions and holistic concepts which define indigenous communities (e.g. culturally specific local dynamics, connections to place, language and social relationships)'.

\section{CROSS-CULTURAL RESEARCH: THE CASE OF THE MUTTONBIRD HARVEST IN AOTEROA (NEW ZEALAND)}

Māori have always been part-cultivators, part-hunters, gatherers and fishers. This example of the muttonbird harvest in southern New Zealand shows how different knowledges and norms can be brought together to result in a better 
understanding of signals about ecological systems, as well as the development of practices that maintain cultural preferences.

The wild harvest, mahinga kai, has deep cultural significance, as it is about obtaining unique foods from specific places at particular times, which are then shared, bringing people together. On Stewart Island, Rakiura, the annual harvest of titit (sooty shearwaters, Puffinus griseus) in late autumn does precisely this. The 1840 Treaty of Waitangi was a legally binding agreement between the British crown and Māori chiefs. It allowed the colonists to settle, and granted Māori full, exclusive and undisturbed possession of their lands, estates, forests and fisheries. Despite the apparently unequivocal language, room for interpretation has been assumed. There remains widespread scepticism amongst certain groups in New Zealand about Māori being able to manage their own resources, despite the fact that ecological problems are widespread elsewhere in society and the landscape. The harvest of young sooty shearwaters between the beginning of April and end of May takes place on 36 tītī islands around Rakiura, and mhänau (families) hold exclusive rights to birding areas. These manu (wild foods) are culturally important; once allocated, they stay with the family. The harvest is thus not just about gathering food, it reaffirms family, friends, wider social links as well as ancestral ones, and being closely connected with a wild place.

The shearwater is an apex marine predator, spending a large part of the year over the south and central Pacific. They nest in southern New Zealand, but also in Australian Tasmania, New South Wales and Victoria. The population of these petrels is estimated to be some 20 million birds (Newman et al. 2009). However, evidence seemed to indicate a long-term decline in tītī. Henrik Moller of the University of Otago began working with Māori on Rakiura from the mid-1990s (Newman et al. 2009; Moller et al. 2009; Stephensen \& Moller 2009). The combination of scientific methods and knowledge with màturanga (traditional knowledge) has led to new insights, including one on climate change. The research relationship has not always been easy, as preconceptions about the methods and worldviews differ. But trust was built over time. Birders claim that there is a greater breeding density closer to the edge of island, and that fledging birds emerge from burrows earlier on western sides of islands: both were both shown scientifically to be true. The scientists now acknowledge their specific skills, and also that birders' māturanga relates not just to the harvest, but to a wider understanding of ecological patterns and relationships. As trust was built, birders then offered Moller their diaries that had been kept for up to 50 years, many of which contained details of weather, tallies, harvest effort and unusual weather events. This unique data then led to a breakthrough, a statistical analysis revealed a link between harvests and the onset of El Nino years. Crucially, low harvests in April-May predict the onset of an El Nino shift later in the same year. It is not yet known why, but changes must be occurring to conditions in the Pacific prior to breeding, perhaps to abundance of anchovy and sardine prey or disruption of wind patterns that prevent the birds finding land (Lyver et al. 1999; Moller et al. 2010).

\section{GOING BEYOND THE STEREOTYPES OF HUNTER-GATHERERS, FORAGERS AND FARMERS}

Linked to the problems initially faced in the muttonbird case, it is also true that external perceptions of ways of managing the land through agricultural to hunting and foraging systems have hindered policies and practices by assuming evolutionary stages to cultures. It has long been held that hunter-gatherer and foraging societies are simply survivors of an earlier stage of cultural evolution, or even the outcome of cultural devolution (Barnard 1999). A common assumption has been that cultures progress in linear fashion from hunter-gatherer to agricultural and then to industrial phases (see Bird Rose 1996; Lee \& Daly 1999). Early perspectives centred on the division of people into either natural or civilized categories. In the 18th century, Rosseau saw hunter-gatherer lives as idyllic, but still replaced by agriculture and metallurgy. Montesquieu called hunters and herders 'savage peoples', and Adam Smith used more evolutionary terminology to set out his four ages of humanity: from hunters to shepherds to agriculture and finally to commerce. In the 19th century, Hegel described the 'savage [as] lazy and distinguished from the educated man by his brooding stupidity', and Engels described three levels before progression to modern: 'lower, middle and upper savagery'. In the early 20th century, Freud described Australian Aborigines as 'the most backward and miserable of savages.' Such widespread and normative cultural views persisted into the late 20th century (Meggers 1954; Lathrap 1968). For example, Lathrap (1968) used terms such as devolution, degradation and wreckage of former agricultural societies to describe communities in the Amazon that engage in hunting, gathering and foraging (see also Barnard 1999).

The evidence, though, revealed these perspectives to be limited (Kent 1989; Kelly 1995). The landmark Man the Hunter conference and subsequent book (Lee \& DeVore 1968) showed hunter-gatherer communities to be culturally-rich, knowledgeable, sophisticated, not-overworked and, above all, different from one another. Lee and DeVore (1968) stated there was no single stage of human development, just different adaptations to local ecological and social circumstances. The new paradigm was summarized by Sahlins' (1968) observation that the Ju/'hoansi (then called !Kung) and other huntergatherers were the 'original affluent society'. It is now morewidely accepted that cultures are adapted to localities, and thus are configured with a wide variety of land uses and livelihoods. As a result, foraging and farming in large parts of the world are actually 'overlapping, interdependent, contemporaneous, coequal and complementary' (Sponsel 1989). This suggests that many rural people and their cultures might be better known as variants of cultivator-hunters or farmer-foragers, rather than just farmers or hunter-gatherers. Once again, this 
indicates that culture and nature are bound together (Berkes 2008; Pretty et al. 2010).

Another stereotype suggests that hunter-gatherers are nomadic and cultivators sedentary. Again, the evidence shows a bewildering array of adaptations and cultural choices. Some horticulturalists move, some hunter-gatherers are sedentary (Vickers 1989; Harris and Hillman 1989; Kelly 1995). Some groups maintain gardens for cultivated food, as well as to attract antelopes, monkeys and birds for hunting. Many apparently hunter-gatherer and forager cultures farm; many agricultural communities use large numbers of wild (nondomesticated) resources. Szuter and Bayham (1989) thus observed that the 'convenient labels of hunter-gatherer or farmer are of minimal value... The two activities are complementary'.

What has become clear is that farmers, hunters, gatherers, fishers and foragers do not simply take resources from a compliant environment (Bharucha \& Pretty 2010). They manage and amend resources in much the same way as is standard practice on farm. Foragers maintain resources by intentional sowing of wild seeds, irrigation of stands of grasses, burning to stimulate plant growth, selective culling of game animals and fish, replanting of portions of roots, enrichment planting of trees and extraction of only parts of honeycombs so sites are not deserted by bees (Steward 1938; Lawton et al. 1976; Woodburn 1980; Kelly 1995). All these management activities have agricultural equivalents, and are variously designed to increase the productivity and stability of useful plants and animals.

Many cultures and groups directly manage trees on and off the farm. The forest islands of Amazonia were found by Posey (1985) to have emerged as a result of Kayapo directly planting mounds. In the lower Amazon, smallholder farmers continually enrich the forests with desirable fruit, timber and medicinal trees, often broadcasting seeds when cutting timber (Brookfield \& Padoch 2007). In dryland Kenya, acacia (Acacia tortilis) tree recruitment occurs on the sites of abandoned pastoralist corrals that are high in organic matter and nutrients from the penned livestock. Acacia seedpods are a favoured fodder, and some pass through the animals to then germinate in the next season. The result is circular woodlands of dense acacia (Reid \& Ellis 1995; Berkes 2008). Management of common forests and woodlands has become recently successful with the emergence of joint forest management, community forest-user and village-managed forest groups (Ostrom et al. 2002; Pretty 2003; Berkes 2004; Molnar et al. 2007). Worldwide, some 370 Mha of various habitats are estimated to be under community conservation, including 14 Mha managed by 65000 community groups in India and 900000 ha managed by 12000 groups in Nepal.

To many cultures, the ideas of wild, wildlife and wilderness remain problematic. The term wild is commonly used today to refer to ecosystems and situations where people have not interfered, yet we now know that people influence, interfere with and manage most, if not all, ecosystems and their plants and animals. It is widely held across many cultures that non- agricultural animals are sentient, and so should be treated with respect. In northern regions, hunters take care to cultivate wild animals and their populations, and people feel that they influence animals by both their thoughts and actions (Nelson 1983; Brody 2002). Anderson and Nuttall (2004) stated that 'the idea that an animal could be wild is horrifying to northern hunters.' The division between people and animals seems to occur with domestication (with the exception of dogs), and many communities class domesticated animals as more like plants (as non-sentient) than animals (Kent 1989; Tyrrell 2010).

What is common in all cases, whether forager or farmer, is that people pay close attention to what the land and country is telling them. Such knowledge and understanding is then encoded into norms, rules, institutions and stories, and thus forms the basis for continued adaptive management over generations (Basso 1996; Pretty 2007; Berkes 2009). This knowledge is an important capital resource. The result is a huge variety of subsistence strategies that vary spatially as well as over time (Kelly 1995). Over time, strategies change and adapt. Similarly, the Sirionó of Bolivia are both mobile and sedentary, raise crops, naturalize fruit trees in the forest, and fish and hunt (Vickers 1989; Balée 1999). Some 72\% of their calories come from domestic plants, the remainder from the wild. In Siberia, some groups (for example Nia of Tiamyr) adopted reindeer herding in the 19 th century, and further adapted to the presence of fur-bearing species brought into the region (Golovnev 1999). In Botswana, there are both sedentary and nomadic Basarwa, each sub-group adapted to their differing local circumstances (Kent 1989).

\section{REVITALIZATION PROJECTS TO SUSTAIN ECOCULTURES}

Rapid disconnection from nature, place and identity is most felt today by indigenous and non-industrial cultures and groups marginalized by limited wealth, power and status, and suffering from associated social pathologies (Milton 1998; Samson 2003). However, many such communities are now striving to reinvigorate their traditional cultures and reconnect with their homelands, in spite of continuing pressures such as globalization and commodification of resources (Berkes 2001; Pilgrim et al. 2009). Recognizing the health and societal repercussions of being disconnected from nature (Johnston et al. 2007), non-industrial communities in a number of locations are taking action to reclaim or maintain their unique beliefs and practices through ecocultural revitalization projects (so termed for their focus on reconnecting cultural systems with the ecosystems upon which they are based). Like the cultures they seek to rejuvenate, revitalization projects are very diverse, ranging from hunter-support schemes and local food policies to language initiatives and ecotourism projects (Table 2).

These revitalization projects share a similar objective: to maintain or reclaim culture and reconnect to the land for longterm individual and societal health, which at a large enough scale would reflect whole societal norms. Cultures exist in 
Table 2 Types of revitalization projects aimed at sustaining ecocultures (source: Pilgrim et al. 2009).

\begin{tabular}{|c|c|}
\hline Project type & Objectives of project type \\
\hline $\begin{array}{l}\text { Traditional } \\
\text { foods }\end{array}$ & $\begin{array}{l}\text { To increase the consumption of traditional local } \\
\text { foods and revive food collection and preparation } \\
\text { practices }\end{array}$ \\
\hline $\begin{array}{l}\text { Traditional } \\
\text { healthcare }\end{array}$ & $\begin{array}{l}\text { To revive knowledge of traditional healthcare } \\
\text { practices including the preparation and } \\
\text { ethnobotanical skills they are based upon }\end{array}$ \\
\hline Ecotourism & $\begin{array}{l}\text { To revive traditional cultural practices and } \\
\text { ceremonies as part of an income generating } \\
\text { strategy }\end{array}$ \\
\hline Education & $\begin{array}{l}\text { To provide a more balanced, } \\
\text { culturally-appropriate education system either } \\
\text { separate from or as part of a state education } \\
\text { system }\end{array}$ \\
\hline Language & $\begin{array}{l}\text { To protect or enhance the competency of speakers } \\
\text { of endangered languages and open } \\
\text { communication channels between community } \\
\text { elders and young people }\end{array}$ \\
\hline Cultural & $\begin{array}{l}\text { To revive particular aspects of a way of life that } \\
\text { may have been neglected }\end{array}$ \\
\hline Rights & $\begin{array}{l}\text { To campaign for the recognition of the human } \\
\text { rights and land rights of indigenous cultures } \\
\text { with a view to ensuring cultural continuity and } \\
\text { diversity into the future }\end{array}$ \\
\hline
\end{tabular}

many different contexts today, for instance in science, policy and business, and not all cultural ideas and practices are good for nature.

Today, revitalization projects are evolving independently of one another amongst communities and groups of communities across the world, at a time when international policy-makers are only just starting to acknowledge the interdependence between human and environmental health (for example UNESCO [United Nations Educational, Scientific and Cultural Organization]'s Man and the Biosphere Program and UNEP [United Nations Environment Programme]'s Global Environment Outlook). Traditional food, healthcare, language and culture projects focus on reviving specific elements of community culture, such as local diets, medicines, languages, ceremonial traditions and land-based practices (for example specialized hunting techniques). Ecotourism projects have a similar objective, but use these cultural elements as an income-generating strategy to encourage tourist activity. Education projects focus on developing culturally-appropriate education schemes and transferring traditional knowledge and practices to younger generations. Rights revitalization efforts are based on the renewal and strengthening of traditional rights, most commonly land rights.

Foods play a role above and beyond nutrition in all human societies. They help to define identity and shape social structure, and are often used in communication, group activities and religious observances. As a result, it is not uncommon for traditional foods to be a major defining characteristic of society. Local diets epitomize the ways in which a culture uses, classifies and thinks about its natural resources, and strengthens the connection between a society, its landscape and its ancestral roots (Pars et al. 2001; Pretty 2002; Tansey 2004; Raine 2005; Willows et al. 2009). Moreover, there is a growing evidence base which suggests that traditional diet can offer physical health benefits (Samson \& Pretty 2006; Johnston et al. 2007; Pretty 2007).

Compared with the low saturated fat, low sugar and low salt diets most non-industrial communities are used to, highly processed store bought foods, combined with the lack of physical exercise needed to acquire them, has led to substantial health costs, including obesity and related diseases such as hypertension and heart disease (Cordain et al. 2000; Kozlov \& Zdor 2003). Recognizing this, a number of revitalization projects have been established to reintroduce traditional foods into modern diets (Marquardt \& Caulfield 1996; Nuttall 1998; Kishigami 2000; OHEP [Ontario's Hunter Education Programme] 2008).

A range of incentives from local organizations and national governments are being used to promote this shift from modern to traditional foods, including the creation of markets for local foods (Marquardt \& Caulfield 1996; Nuttall 1998). However, reintroduction comprises more than just renewed consumption. In many cases, communities are reviving the livelihood skills, practices and knowledge needed to find, collect and prepare traditional foods. In the Inuit communities of Akulivik (Quebec, Canada), a hunter-support programme has been established to provide economic support for hunters whilst ensuring the distribution of traditional foods. Market channels have been created so that hunters in local communities can sell the meat and fish they catch to village councils for redistribution. Each village councillor is given a portion of the project funds to pay hunters and to buy and repair equipment. Every village that participates in the project is entitled to a community hunting boat and a communal cold storage house. If project funds are not used locally for hunter and fisher wages, then monies may be used to buy fish and meat from nearby villages to distribute amongst community members, in particular widows, elders or fulltime wage earners who are unable to hunt. This provides local hunters with an income source and ensures continued consumption of traditional foods (Kishigami 2000).

The Greenland Home Rule government has created a similar market but on a national scale by prioritizing the promotion and expansion of traditional country food markets. The government distributes licences (for commercial hunters and fishers, and nationals unemployed for over 125 days per year) and territories to communities, and in doing so, ensures livelihoods and healthy diets even in isolated communities and settlements. At the same time, residents of industrial towns who do not have the time to hunt (for example on the west coast) are able to purchase healthier traditional foods (Nuttall 1998). To ensure price competition does not drive down populations, all country foods are sold at fixed prices agreed upon by the local hunters' and fishers' association (Marquardt \& Caulfield 1996; Pars et al. 
2001). Hunters are encouraged to sell their surplus catch to Royal Greenland, the national meat and fish processing and distribution company. By providing a source of full time income, or even supplementary income for households, the marketization of country foods in Greenland has increased the self sufficiency and cultural continuity of Greenlandic communities (Marquardt \& Caulfield 1996; Nuttall 1998; Pars et al. 2001). The success of the Greenlandic government demonstrates that an indigenous hybrid economy exists based on a three sector model: private, public and customary. In this economy, customary activities are integrated into the global capitalist economy (Altman 2005).

Thus some traditional foods revitalization projects have succeeded in market creation, the establishment of support programmes, the creation of new businesses, in particular the emergence of micro-enterprise, and incentivizing traditional food collection and consumption. This indicates a potential link to the modern economy of most countries.

\section{BETTER INTEGRATION FOR THE FUTURE}

Ecocultural revitalization projects offer insight into elements that may also be used to reconnect industrial communities undergoing long-term disconnections from nature. They share a similar objective: to maintain or reclaim the culture of local peoples and reconnect them to the land for longterm individual and societal health. Revitalization projects are very diverse, ranging from hunter-support schemes and local food policies to language initiatives and ecotourism projects. Four intrinsic components must be sustained for some degree of cultural continuity: (1) beliefs, meanings and worldviews, (2) livelihoods, practices and resource management systems, (3) knowledge bases and languages, and (4) institutions, norms and regulations. All four must be sustained if cultural continuity is to be successfully attained (noting that cultural resilience does not imply no cultural change; rather it suggests the need to maintain core natural and social components of cultures in the face of externally-driven change) (Pretty et al. 2010).

For instance, green exercise and green care initiatives are an emerging trend, particularly in the UK and across Europe (Barton \& Pretty 2010). Such projects offer health benefits to participants, have the capacity to create and strengthen social relationships, and are open to all community cohorts. At the same time, there is a need for better integration of disciplines to address the needs of socialecological systems of all types. The need for a parallel approach to the conservation of biological and cultural diversity has been acknowledged in the Millennium Development Goals. However, policy responses to this perspective have been slow to emerge, partly because outcomes (benefits and costs) have not been measured clearly. Responses to date include local recovery projects and revitalization schemes such as outpost and hunter-support programmes, culturallyappropriate education schemes, ecotourism projects and language revitalization initiatives. Other revitalization efforts include the revival of culturally-appropriate healthcare systems, the protection and careful commercialization of traditional food systems, and the greening of businesses.

The emergence of revitalization projects has been in response to shared concerns about disconnection from nature and motivations to revive traditional ways of living through reconnection with the land. They are commonly initiated by elders who perceive younger generations to be disconnected from both their culture and nature (Johnston et al. 2007). Chamorro cultures in Guam (USA) employ a range of different approaches, including culture camps, craft workshops, language projects and the revival of traditional fishing practices. In southern Siberia, ecotourism efforts are being combined with Tuvan livestock camps dedicated to teaching the skills of nomadic pastoralism to young Tuvinians (Pretty 2009). In Labrador (Canada), the Tshikapisk Foundation is an organization of indigenous people engaging outsiders such as ecotourists, biologists, artists, students and wildlife enthusiasts with local Innu who wish to perpetuate their hunting life. Tshikapisk have also established initiatives to assist with the inter-generational transmission of Innu knowledge through canoe trips, walks, and hunting expeditions (Samson \& Pretty 2006). Other longstanding initiatives, such as the outstation programme in Australia that funds Aboriginal people who wish to engage in traditional ways of living, are treated as anachronisms and thus severely underfunded (Altman 2002; Johnston et al. 2007).

Policy-makers dealing with disconnected communities can look towards natural and cultural revitalization for insights into long-term and wider solutions. Revitalization offers a community-centred approach combined with multiple science inputs to deal with the problems of disconnection. In some cases communities have developed their own political, economic and social organization that could not exist without strong connections to the land and cultural identity (Alfred 2009). By being locally-driven, projects are more likely to encourage long-term support and participation, and have the capacity to empower non-industrial peoples, thus reinvigorating communities, cultures and connections with the land. Larger-scale initiatives that protect biological and cultural diversity include the fair-trade movement, other certification programmes, and the granting of land rights to indigenous and other rural people, for instance in the designation of the Nunavut Inuit territory in Canada. Investment into community-based conservation and the dissemination of power to grassroots initiatives and institutions has increased, strengthening the mechanisms that favour ecocultural system sustainability. Entrepreneurshipbased conservation development projects are also emerging (UNEP 2007). However, many efforts remain fragmented, localized and small-scale.

A great deal still needs to be done in the international arena. A paradigm shift is needed to transform the way all groups think about global diversity, whereby biological and cultural diversity are thought of as parts of the same whole. One important development has been a dramatic reshaping 
of the way in which protected areas are conceived. There is increasing recognition of the importance of indigenous and community conserved areas (Robson \& Berkes 2010), areas managed by local communities in ways that support high levels of biodiversity but which often have no official protected status (Borrini-Feyerabend et al. 2004). There is also growing agreement that cultural landscapes are worthy of protection (IUCN [International Union for Conservation of Nature] Category V Protected Areas) where the interaction of humans and nature over time has produced a particular set of natural and cultural conditions (Phillips 2002). Emerging partnerships between faith groups and conservation science present another powerful opportunity (Dudley et al. 2006). Policies emphasizing political empowerment, self-governance and territorial control at the grass-roots level have the potential to provide a solid platform from which communities can play a central role in biodiversity conservation at the same time as retaining their own cultural distinctiveness and connectedness to the land (Colchester 2000; Schwartzman et al. 2000; Peres \& Zimmerman 2001; Heckenberger 2004; Athayde et al. 2007).

The degree to which the diversity of the world's ecosystems is linked to the diversity of its cultures is only beginning to be understood. There is clearly now a need for more integrated research and more practice. While conserving nature alongside human cultures presents unique challenges, any hope for saving biological diversity, or even recreating lost environments through restoration ecology, will require a concomitant effort to appreciate, protect and support cultural diversity. Where communities have succeeded in sustaining ecocultures, there are lessons that can be learned, with emergent approaches that can be used by other communities (human and ecological) around the world. However, their scale is not yet sufficient to overturn the global trends noted at the beginning of this paper. The need to overcome and bridge preexisting boundaries remains critical, as does the evaluation of impacts and spread of lessons learned. Going beyond the current boundaries (for example between disciplines, understandings, cultures, paradigms, worldviews, languages and institutional frameworks) with the use of novel tools and mechanisms could help to overcome these divides.

\section{ACKNOWLEDGEMENTS}

I am grateful to Henrik Moller, Nicholas Polunin and one anonymous referee for their very helpful comments and observations on an earlier version of this paper.

\section{References}

Abel, N., Cumming, D.H.M. \& Anderies, J.M. (2006) Collapse and reorganization in social-ecological systems: questions, some ideas, and policy implications. Ecology and Society 11(1): 17.

Adams, W.M. (1996) Future Nature: A Vision for Conservation. London, UK: Earthscan.

Adger, N. (2005) Vulnerability. Global Environmental Change 16(3): 268-281.
Adger, W.N., Hughes, T.P., Folke, C., Carpenter, S.R. \& Rockstrom, R. (2005) Social-ecological resilience to coastal disasters. Science 309: 1036-1039.

Anderson, D.G. \& Nuttall, M., eds (2004) Cultivating Arctic Landscapes. New York, NY, USA \& Oxford, UK: Berghahn.

Albrecht, G. (2010) Solastalgia and the creation of new ways of living. In: Nature and Culture, ed S.E. Pilgrim \& J. Pretty, p. 217. London, UK: Earthscan.

Alfred, T. (2009) Colonialism and State Dependency. National Aboriginal Health Organization Project Communities in Crisis. Canada: University of Victoria.

Altman, J. (2005) The indigenous hybrid economy, realistic sustainable option for remote communities: radical approach or plain common sense? Address to the Australian Fabian Society, 26 October 2005 [www document]. URL http://caepr.anu. edu.au/system/files/Publications/topical/Altman_hybrid.pdf

Athayde, S.F., Kaiabi, A., Ono, K.Y. \& Alexiades, M.N. (2007) Weaving power: displacement and the dynamics of artistic knowledge amongst the Kaiabi in the Brazilian Amazon. In: Mobility and Migration in Indigenous Amazonia, ed. M.N. Alexiades. Oxford, UK: Berghahn.

Balee, W. (1994) Footprints of the Forest: Ka' apor Ethnobotany. New York, NY, USA: Columbia University Press

Balée, W. (1999) Principles of Historical Ecology. New York, NY, USA: Colombia University Press

Barnard, A. (1999) Images of hunter and gatherers in European social thought. In: Cambridge Encyclopedia of Hunters and Gatherers, ed. R.B. Lee \& R Daly, pp. 375-383. Cambridge, UK: Cambridge University Press.

Barton, J. \& Pretty, J. (2010) What is the best dose of nature and green exercise for mental health? A meta-study analysis. Environmental Science and Technology 44: 3947-3955.

Basso, K. (1996) Wisdom Sits in Places. Albuquerque, NM, USA: University of New Mexico Press.

Berkes, F. (2001) Religious traditions and biodiversity. Encyclopaedia of Biodiversity 5:109-120.

Berkes, F. (2004) Rethinking community-based conservation. Conservation Biology 18(3): 621-630.

Berkes, F. (2008) Sacred Ecology. Second edition. New York, NY, USA: Routledge

Berkes, F. (2009) Indigenous ways of knowing and the study of environmental change. Fournal Royal Society of Nem Zealand 39: 151-156.

Berkes, F., Colding, J. \& Folke, C. (2000) Rediscovery of traditional ecological knowledge as adaptive management. Ecological Applications 10: 1251-1262.

Berkes, F., Colding, J. \& Folke, C. (2003) Navigating SocialEcological Systems. Building Resilience for Complexity and Change. Cambridge, UK: Cambridge University Press.

Berkes, F., Huebert, R., Fast, H., Manseau, M. \& Diduck, A., eds (2005) Breaking Ice: Renemable Resource and Ocean Management in the Canadian North. Calgary, Canada: University of Calgary Press.

Bharucha, Z. \& Pretty, J. (2010) The roles and values of wild foods in agricultural systems. Philosophical Transactions Royal Society London B 365 (1554), 2913-2926

Bird Rose, D. (1996) Dingo Makes Us Human. Life and Land in an Australian Aboriginal Culture. Cambridge, UK: Cambridge University Press

Borrini-Feyerabend, G., Kothari, A. \& Oviedo, G. (2004) Indigenous and Local Communities and Protected Areas. Cardiff, UK and Cambridge, UK: Cardiff University and IUCN. 
Brody, H. (2002) The Other Side of Eden. London, UK: Faber \& Faber.

Brookfield, H. \& Padoch, C. (2007) Managing biodiversity in spatially and temporally complex agricultural landscapes. In: Managing Biodiversity in Agricultural Systems, ed. D.I. Jarvis, C. Padoch \& H.D. Cooper, pp. 338-361. New York, NY, USA: Columbia University Press.

Brown, L.R. (2008) Plan B 3.0: Mobilizing to Save Civilization. New York, NY, USA: W.W. Norton.

Cernea, M. (1997) The risks and reconstruction model for resettling displaced populations. World Development 25: 1569-1587.

Clark, W.C. \& Dickson, N.M. (2003) Sustainability science: the emerging research program. Proceedings of the National Academy of Sciences USA 100: 8059-61.

Colchester, M. (2000) Self-determination or environmental determinism for indigenous peoples in tropical forest conservation. Conservation Biology 14: 1365-1367.

Cordain, L., Miller, J.B., Eaton, S.B., Mann, N., Holt, S.H.A. \& Speth, J.D. (2000) Plant-animal subsistence ratios and macronutrient energy estimations in worldwide hunter-gatherer diets. American fournal of Clinical Nutrition 71: 682-692.

Costanza, R., Graumlich, L.J. \& Steffen, W., eds (2007) Sustainability or Collapse? Cambridge, MA, USA: MIT Press.

Darnhofer, I., Fairweather, J. \& Moller, H. (2010) Assessing a farm's sustainability: insights from resilience thinking. International Fournal of Agricultural Sustainability 8(4): (in press).

Denevan, W.M. (2001) Cultivated Landscapes of Native Amazonia and the Andes. Oxford, UK: Oxford University Press.

Diamond, J. (2005) Collapse: How Societies Choose to Fail or Survive. London, UK: Penguin.

Dove, M. \& Carpenter, C. (2008) Environmental Anthropology: a Historical Reader. Boston, MA, USA: Blackwell.

Dudley, N., Higgins-Zogib, L. \& Mansourian, S. (2006) Beyond Belief: Linking Faiths and Protected Areas to Support Biodiversity Conservation. Gland, Switzerland and Manchester, UK: WWF and Alliance of Religions and Conservation.

Escobar, A. (2008) Territories of Difference: Place, Movements, Life. Redes, USA: Duke University Press.

Folke, C., Colding, J., Olsson, P. \& Hahn, T. (2007) Interdependent social-ecological systems. In: Sage Handbook on Environment and Society, ed. J. Pretty, A. Ball, T. Benton, J. Guivant, D. Lee, D. Orr, M. Pfeffer \& H. Ward, pp. 536-552. London, UK: Sage.

Gadgil, M., Seshagiri Rao, P.R., Utkarsh, G., Pramod, P., Chhatre, A. \& members of the People's Biodiversity Initiative (2000) New meanings for old knowledge. Ecological Applications 10: 1307-17.

Godfray, C., Beddington, J.R., Crute, I.R., Haddad, L., Lawrence, D., Muir, J.F., Pretty, J., Robinson, S., Thomas, S.M. \& Toulmin, C. (2010) Food security: the challenge of feeding 9 billion people. Science 237: 812-818.

Golovnev, A V. (1999) Nia (Nganasan). In: Cambridge Encyclopedia of Hunters and Gatherers, ed. R.B. Lee \& R Daly, pp. 166-169. Cambridge, UK: Cambridge University Press.

Gunderson, L.H. \& Holling, C.S., eds (2002) Panarchy: Understanding Transformations in Human and Natural Systems. Washington, DC, USA: Island Press.

Harmon, D. (2002) In Light of Our Differences. Washington, DC, USA: Smithsonian Institution Press.

Harris, D.R. \& Hillman, G.C., eds (1989) Foraging and Farming. London, UK: Unwin Hyman.

Heckenberger, M.J. (2004) Archeology as indigenous advocacy in Amazonia. Practicing Anthropology 26: 34-38.
Holling, C.S. (1973) Resilience and stability of ecological systems. Annual Reviem of Ecology Systematics 4: 1-23.

Jackson, T. (2009) Prosperity Without Gromth. London, UK: Earthscan.

Jacobson, C. \& Stephens, A. (2009) Cross-cultural approaches to environmental research and management: a response to the dualisms inherent in Western science? Fournal of the Royal Society of Nem Zealand 39: 159-162.

Johnston, F.H., Jacups, S.P., Vickery, A.J. \& Bowman, D.M.J.S. (2007) Ecohealth and aboriginal testimony of the nexus between human health and place. EcoHealth 4: 489-499.

Kates, R.W., Clark, W.C., Corell, R., Hall, J.M., Jaeger, C.C., Lowe, I., McCarthy, J.J., Schellnhuber, H.J., Bolin, B., Dickson, N.M., Faucheux, S., Gallopin, G.C., Grubler, A., Huntley, B., Jager, J., Jodha, N.S., Kasperson, R.E., Mabogunje, A., Matson, P., Mooney, H., Moore, B., T. O'Riordan, T. \& Svedlin, U. (2001) Sustainability science. Science 292: 641-642.

Kelly, R.L. (1995) The Foraging Spectrum: Diversity in HunterGatherer Lifemays., Washington, DC, USA: Smithsonian.

Kent, S., ed. (1989) Farmers as Hunters: The Implications of Sedentism. Cambridge, UK: Cambridge University Press.

Kishigami, N. (2000) Contemporary Inuit food sharing and hunter support program of Nunavik, Canada. In: The Social Economy of Sharing: Resource Allocation and Modern Hunter-Gatherers, ed. G. W. Wenzel, G. Hovelsrud-Broda \& N. Kishigami, Senri, Ethnological Studies, Vol 53, pp. 171-192. Osaka, Japan: National Museum of Ethnology.

Kozlov, A.I. \& Zdor, E.V. (2003) Whaling products as an element of indigenous diet in Chukotka. Anthropology of East Europe Review: Central Europe, Eastern Europe and Eurasia. Food and Foodways 21: 127-137.

Lathrap, D.W. (1968) The hunting economics of the tropical forest zone of South America. In: Man the Hunter, ed. R.B. Lee \& I. DeVore. Chicago, IL, USA: Aldine.

Lawton, H., Wilkie, P., Decker, M. \& Mason, W. (1976) Agriculture among the Paiute of Owens Valley. Fournal of Californian Anthropology 3: 13-50.

Lee, R.B. \& Daly, R. (1999) The Cambridge Encyclopedia of Hunters and Gatherers. Cambridge, UK: Cambridge University Press.

Lee, R.B. \& DeVore, I., eds (1968) Man the Hunter. Chicago, IL, USA: Aldine.

Lyver, P., Moller, H. \& Thompson, C. (1999) Changes in sooty shearwater (Puffinus griseus) chick production and harvest precede ENSO events. Marine Ecology Progress Series 188: 237248.

MA (2005) Millennium Ecosystem Assessment. Washington, DC, USA: Island Press.

Maffi, L. (1998) Language: a resource for nature. Nature and Resources 34: 12-21.

Maffi, L., ed. (2001) On Biocultural Diversity. Washington, DC, USA: Smithsonian Institution Press.

Marquardt, O. \& Caulfield, R.A. (1996) Development of West Greenlandic markets for country foods since the 18th century. Arctic 49:107-119.

Mascia, M. (2006) Conservation social science: what's in the black box? Society for Conservation Biology Nemsletter 13(2): 1.

Mascia, M., Brosius, J.P., Dobson, T.A., Forbes, B.C., Horowitz, L., McKean, M.A. \& Turner, N.J. (2003) Conservation and the social sciences. Conservation Biology 17: 649-650.

Meggers, B.J. (1954) Environmental limitations on the development of culture. American Anthropologist 56: 801-824. 
Milton, K. (1998) Nature and the environment in indigenous and traditional cultures. In: Spirit of the Environment: Religion, Value and Environmental Concern, ed. D.E. Cooper \& J.A. Palmer. London, UK and New York, NY, USA: Routledge

Moller, H., Kitson, J.C. \& Downs, T. (2009) Knowing by doing: learning by sustainable muttonbird harvesting. Nem Zealand Journal of Zoology 36: 243-258.

Moller, H., Newman, J., Lyver, P.O'B. \& Rakiura Tìtī Islands Administering Body (RTIAB) (2010) Fourteen years on: lessons for community-led science partnerships from the Kia Mau te Tìtī Mo Ake Tōnu Atu project. In: Ngā Kete a Rēhua Inaugural Māori Research Symposium Te Waipounamu 2008, ed. R. Taonui, H. Kahi, C. Deeming, K. Kururangi, G. Cooper, L. Ratahi, M. Royal, R. Taonui, M. Haenga \& J. Bray. Aotahi, New Zealand: School of Māori and Indigenous Studies, University of Canterbury.

Molnar, A., Scherr, S.J. \& Khare, A. (2007) Community stewardship of biodiversity. In: Farming with Nature, ed. S.J. Scherr \& J.A. McNeely, pp. 268-285. Washington, DC, USA: Island Press.

Nelson, R. (1983) Make Prayers to the Raven. Chicago, IL, USA: University of Chicago Press.

Newman, J. \& Moller, H. (2005) Use of Mātauranga (Māori traditional knowledge) and science to guide a seabird harvest: getting the best of both worlds? Senri Ethnol Studies 67: 303-21.

Newman, J., Scott, D., Bragg, C., McKechnie, S., Moller, H. \& Fletcher, D. (2009) Estimating regional population size and annual harvest intensity of the sooty shearwater in New Zealand. Nem Zealand Journal of Zoology 36: 307-323.

Norgaard, R.B. (1994) Development Betrayed. London, UK: Routledge.

Nuttall, M. (1998) Protecting the Arctic: Indigenous Peoples and Cultural Survival. Amsterdam, the Netherlands: Harwood Academic.

OHEP (2008) Ontario's Hunter Education Program [www document]. URL http://www.ohep.net

Ostrom, E. (1990) Governing the Commons: The Evolution of Institutions for Collective Action. Cambridge, UK: Cambridge University Press.

Ostrom, E., Dietz, T., Dosčak, N., Stern, P.C., Stonich, S \& Weber, E.U., eds (2002) The Drama of the Commons. Washington, DC, USA: National Academy Press.

Pars, T., Osler, M. \& Bjerregaard, P. (2001) Contemporary use of traditional and imported food among Greenlandic Inuit. Arctic 54(1): 22-31.

Peres, C. \& Zimmerman, B. (2001) Perils in parks or parks in peril? Conservation Biology 15: 793-797.

Phillips, A. (2002) Management Guidelines for IUCN Category $V$ Protected Areas: Protected Landscapes and Seascapes. Cambridge, UK and Cardiff, UK: IUCN and University of Cardiff.

Pilgrim, S.E. \& Pretty, J., eds (2010) Nature and Culture. London, UK: Earthscan.

Pilgrim, S., Cullen, L., Smith, D.J. \& Pretty, J. (2008) Ecological knowledge is lost in wealthier communities and countries. Environmental Science and Technology 42: 1004-1009.

Pilgrim, S., Samson, C. \& Pretty, J. (2009) Rebuilding lost connections: how revitalisation projects contribute to cultural continuity and improve the environment. iCES Occasional Paper, University of Essex, UK.

Pilgrim, S., Smith, D.J. \& Pretty, J. (2007) A cross-regional assessment of the factors affecting ecoliteracy: implications for policy and practice. Ecological Applications 17: 1742-1751.

Posey, D.A. (1985) Indigenous management of tropical forest ecosystems. Agroforestry Systems 3:139-158.
Posey, D.A., ed. (1999) Cultural and Spiritual Values of Biodiversity. Nairobi, Kenya: UNEP and IT Publications.

Pretty, J. (2002) Agri-Culture. London, UK: Earthscan.

Pretty, J. (2003) Social capital and the collective management of resources. Science 302: 1912-1915.

Pretty, J. (2007) The Earth Only Endures. London, UK: Earthscan.

Pretty, J. (2009) Integrated community development and biodiversity conservation in the Republic of Tyva (Siberia, Russian Federation). Report of a Mission to Tyva commissioned by Oxfam GB. University of Essex, Colchester, UK.

Pretty, J., Ball, A.S., Benton, T., Guivant, J., Lee, D., Orr, D., Pfeffer, M. \& Ward, H., eds (2007) Sage Handbook on Environment and Society. London, UK: Sage: $626 \mathrm{pp}$.

Pretty, J., Adams, W., Berkes, F., Ferreira de Athayde, S., Dudley, N., Hunn, E., Maffi, L., Milton, K., Rapport, D., Robbins, P., Sterling, E., Stolton, S., Tsing, A., Vintinner, E. \& Pilgrim, S. (2010) The intersections of biological diversity and cultural diversity: towards integration. Conservation and Society 7(2): 100 112.

Raine, K.D. (2005) Determinants of healthy eating in Canada. Canadian Fournal of Public Health 96(supplement 3): S8-S14.

Rapport, D.J. (2006) Sustainability science: an ecohealth perspective. Sustainability Science 2: 77-84.

Rapport, D.J. \& Mergler, D. (2004) Expanding the practice of ecosystem health. EcoHealth 1: 4-7.

Rapport, D.J. \& Whitford, W.G. (1999) How ecosystems respond to stress? Bioscience 49, 193-203.

Rapport, D.J., Costanza, R. \& McMichael, A. (1998) Assessing ecosystem health: challenges at the interface of social, natural, and health sciences. Trends Ecology and Evolution 13: 397402.

Reid, R.S. \& Ellis, J.E. (1995) Impacts of pastoralists in South Turkanba, Kenya. Ecological Applications 5: 978-92.

Robson, J.P. \& Berkes, F. (2010) Sacred nature and community conserved areas. In: Nature and Culture, ed. S.E. Pilgrim \& J Pretty. London, UK: Earthscan.

Rotarangi, S. \& Russell, D. (2009) Social-ecological resilience thinking: can indigenous culture guide environmental management? Fournal Royal Society of Nem Zealand 39: 209-213.

Royal Society (2009) Reaping the Benefits. London, UK: Royal Society.

Sahlins, M. (1968) Stone Age Economics. Chicago, IL, USA: Aldine.

Samson, C. (2003) A Way of Life that Does Not Exist. St Johns, Canada: ISER.

Samson, C. \& Pretty, J. (2006) Environmental and health benefits of hunting lifestyles and diets for the Innu of Labrador. Food Policy 31(6): 528-553.

Schwartzman, S., Moreira, A. \& Nepstad, D. (2000) Rethinking tropical forest conservation: perils in parks. Conservation Biology 14: 1351-1357.

Sponsel, L.E. (1989) Farming and foraging: a necessary complementarity in Amazonia? In: Farmers as Hunters, ed. S Kent. Cambridge, UK: Cambridge University Press.

Stephenson, J. (2007) Many perceptions, one landscape. Landscape Reviem 11(2): 9-30.

Stephenson, J. \& Moller, H. (2009) Cross-cultural environmental research and management. Fournal Royal Society of Nem Zealand 39: $139-49$.

Steward, J.H. (1938) Basin Plateau Aboriginal Sociopolitical Groups. Washington, DC, USA: Bureau of American Ethnology Bulletin 120 . 
Szuter, C.R. \& Bayham, F.E. (1989) Sedentism and prehistoric animal procurement among desert horticulturalists of the North American Southwest. In: Farmers as Hunters, ed. S Kent. Cambridge, UK: Cambridge University Press.

Sutherland, W.J. (2003) Parallel extinction risk and global distribution of languages and species. Nature 423: 276279.

Tansey, G. (2004) A food system overview. In: Protecting and Promoting Traditional Knomledge, ed. S. Twarog \& P. Kapoor, pp. 41-58. Geneva, Switzerland: United Nations.

Toledo, V.M. (2001) Biodiversity and indigenous peoples. Encyclopaedia of Biodiversity 3: 451-463.

Turner, N. \& Berkes, F. (2006) Coming to understanding: developing conservation through incremental learning in the Pacific Northwest. Human Ecology 34: 495-513.

Tyrrell, M (2010) Biodiversity and cultural diversity. In: Nature and Culture, ed. S.E. Pilgrim \& J Pretty. London, UK: Earthscan.

UNEP (2007) Global Environment Outlook 4 (GEO-4). Nairobi, Kenya: UNEP.

Vickers, W.T. (1989) Patterns of foraging and gardening in a semi-sedentary Amazonian community. In: Farmers as Hunters, ed. S Kent, pp. 46-59. Cambridge, UK: Cambridge University Press.
Walker, B.H., Anderies, J.M., Kinzig, A.P. \& Ryan, P. (2006) Exploring resilience in social-ecologicalsystems through comparative studies and theory development: introduction to the special issue. Ecology and Society 11(1): 12 [www document]. URL http://www.ecologyandsociety.org/vol11/iss1/art12/

Westley, F., Carpenter, S.R., Brock, W.A., Holling, C.S. \& Gunderson, L.H. (2002) Why systems of people and nature are not just social and ecological systems. In: Panarchy. Understanding Transformations in Human and Natural Systems, ed. L.H. Gunderson \& C.S. Holling, pp. 103-119. Washington DC, USA: Island Press.

Williams, J. (2009) 'O ye of little faith': traditional knowledge and western science. Fournal Royal Society of Nem Zealand 39: 167169.

Willows, N.D., Veugelers, P., Raine, K. \& Kuhlein, S. (2009) Prevalence and sociodemographic risk factors related to household food security in Aboriginal peoples in Canada. Public Health Nutrition 12: 1150-56.

Woodburn, J. (1980) Hunters and gatherers today and reconstruction of the past. In: Soviet and Western Anthropology, ed. A. Gellner, pp. 95-117. London, UK: Duckworth.

Zalasiewicz, J., Williams, M., Steffen, W. \& Crutzen, P. (2010) The new world of the anthropocene. Environmental Science and Technology 44: 2228-2231. 